\title{
The goal of psychological intervention and performed functions of psychologists as an aspect of the professional identity of psychologists: Latvian sample
}

\author{
Elina Akmane ${ }^{1, *}$, Kristine Martinsone ${ }^{1}$, Zane Krieke $^{1}$, Miguel Ricou $^{2,3}$, and Silvia Marina ${ }^{2,3}$ \\ ${ }^{1}$ Riga Stradins University, Department of Health Psychology and Pedagogy, Riga, Latvia \\ ${ }^{2}$ University of Porto, Faculty of Medicine, Porto, Portugal \\ ${ }^{3}$ CINTESIS - Centre for Health Technology and Services Research, Porto, Portugal
}

\begin{abstract}
Professional identity is formed by combination of several aspects, including professional practice, which for psychologists relates to psychological intervention and performed functions. The exclusive goal of psychological intervention and exclusively performed functions of psychologists are an important research subjects because more and more practicing professionals are performing activities linked to psychological intervention. The purpose of this paper was to investigate the exclusive goal of psychological intervention and exclusively performed functions of Latvian psychologists. Data was collected through an online survey developed in the framework of the international project "The Identity of Psychology" [1]. Three open-answer questions were used. Sample consisted of 54 Latvian psychologists of which $91 \%$ were women $(n=$ $49)$ and $9 \%$ were men $(n=5)$ aged from 25 to 60 years $(M=44.94 ; \mathrm{SD}=8.98)$. Data was analysed using thematic categorical content analysis. Findings indicate clear diversity in the opinion about the professional practice among Latvian psychologists. The results of this study indicate limited agreement and comprehension of Latvian psychologists about their professional practice which leads to necessity for further research to investigate the causes of such outcome to determine solutions on how to strengthen their professional practice and, more broadly, professional identity.
\end{abstract}

\section{Introduction}

The topicality of the research is marked by the expansion of the field of psychological help, with a focus on performed functions of a psychologist and the goal of psychological intervention and its role in the provision of psychological help, as well as the role of the psychologist as a psychological help provider. The main purpose, according to the goals of the international project "The Identity of Psychology" [1], is to deepen and comprehend the phenomenon associated with psychologists' professional identity. By this - what is the psychologists' own understanding of the uniqueness of the goal of psychological intervention and the performed functions of a psychologist.

\footnotetext{
${ }^{*}$ Corresponding author: elina.akmane@ rsu.lv
} 
There are various theories through which to look at professional identity. Contemporary professional identity researchers comprehensively distinguish three areas through which professional identity is influenced and developed: individual, relational, and collective identity [2, 3]. This study focuses on the exclusive functions of a psychologist and the exclusive goals of psychological intervention in order to understand what professional activities distinguish psychologists from other professionals. Therefore, we chose a theory based on the social context of professional identity and is related to collective identity - Social Identity Theory, which was developed in the 1970s by British social psychologists Henry Tajfel and John Turner [4] and is the most commonly used to define professional identity nowadays as well [5-9]. Authors of Social Identity Theory emphasize the social dimension of identity because the social environment determines any individual identity. We can say that professional identity is a social aspect of individual identity - process in which a person identifies her/himself with a social group, allowing differentiating themselves from other groups [7]. It can be described as the attitudes, values, knowledge, beliefs, and skills that are shared with others within a professional group and relates to the professional role being undertaken by the individual [5]. Ricou et al. point out that in the field of psychology, this is also shown in Portugal and throughout Europe, a set of activities related to psychology is emerging, which, however, stems from different fields of training, philosophy and schools of psychology [1]. Therefore, it is necessary to understand how psychologists themselves understand the goal of psychological intervention and the uniqueness of their performed functions. We should understand the differences between professions in an inter-professional context, since difficulties in identifying clear differences in professional activity and, more broadly, in professional identity can lead to confusion, as well as to convergence of professional roles and functions. It may endanger inter-professional cooperation [6]. In addition, it is important for all psychologists to understand the boundaries of their professional activity in order to make the whole profession stronger in general. Strengthening the various aspects of professional identity is one of the most important aspects of the existence and sustainability of each profession and their study is essential for the development of each profession $[10,11]$.

The formation of a psychologist's professional identity including professional practice is closely related to the historical development of the psychologist's profession in Latvia alongside political, social, and cultural changes. The Law on Psychologists has been in force since 2018, but historically, various schools and educational requirements have formed the profession of psychologist. In the last decade of the 20th century, the education of a psychologist was started in different universities and was characterized by different traditions also receiving education that is diverse in content and scope. That promoted the diverse understanding of psychology in Latvia today. In the early 2000s the first Standard for the profession of psychologist and psychologist's assistant was established, which formed a unified view of the education and its content of a psychologist $[12,13]$. The purpose of the Law on Psychologists is to regulate professional activities by determining the procedure for registration, and certification and recertification of psychologists, dividing the six areas of psychologist's professional activity: educational and school psychology; psychology of work and organizations; clinical and health psychology; legal psychology; consultative psychology; military psychology [14].

Although the profession of psychologist is regulated in Latvia, it is relatively new and, with the emergence of a set of activities associated with psychology, it may be endangered. Ricou et al. [1] point to the threats to the profession of psychologist that characterize an increasingly specialized and flexible world of professional identities. They point out that if 
psychologists do not strengthen their identity, they risk getting lost in that same specialization and flexibility. If psychologists do not identify first with psychology, only then looking for their areas of professional activity inside psychological intervention, they risk assuming other identities.

Taking into account Ricou's et al. research [1] and the proposed framework, it is important to study how Latvian psychologists define the exclusive goals of psychological intervention and functions exclusively performed by psychologists. The aim of this research is to promote the discussion on psychologist's professional identity issues among psychologists in order to define the aspects of the psychologist's professional activity, such as the goal of psychological intervention and performed functions clear to professionals and, through them, to the general public. That will contribute to the promotion of the development of psychology. To reach the aim of this research the following research questions were set: 1) What is the exclusive goal of psychological intervention that makes it unique when compared to any other profession or form of intervention? 2) In your opinion, what functions are exclusively performed by psychologists? 3) In your opinion, what functions performed by psychologists may be performed by other professionals who are not psychologists? The research questions are in line with the applied research instrument.

In order to answer the research questions authors defined the following tasks: 1) To identify the exclusive goal of psychological intervention that makes it unique when compared to any other profession or form of intervention; 2) To identify the functions that are exclusively performed by psychologists; 3 ) To identify the functions performed by psychologists but, as well, may be performed by other professionals who are not psychologists.

\section{Methods}

\subsection{Participants}

Sample consisted of 54 Latvian psychologists of which $91 \%$ were women $(n=49)$ and $9 \%$ were men $(n=5)$ aged from 25 to 60 years $(M=44.94$; SD $=8.98)$. Participants were practising psychologists in one of the specializations 1) Education and school psychology, 2) Psychology of work and organizations, 3) Clinical and health psychology, 4) Legal psychology, 5) Consultative psychology, 6) Military psychology.

\subsection{Instruments}

This study was based on 3 open questions developed in the framework of the international project "The Identity of Psychology" [1]. The questions were:

1) What is the exclusive goal of psychological intervention that makes it unique when compared to any other profession or form of intervention?

2) In your opinion, what functions are exclusively performed by psychologists?

3) In your opinion, what functions performed by psychologists may be performed by other professionals who are not psychologists?

\subsection{Procedure}

Data were collected through online survey in November 2020, which included also three open questions. As this study was a part of a larger research focusing on professional identity aspects of different psychological help providers in Latvia, the data were collected with the support of professional associations. For this research, the three open question answers were analysed. Participants received an e-mail from the professional associations including the information about the aim of the research, confidentiality, and data analysis. With completion of the survey, participants confirmed their participation in this research. 


\subsection{Data analysis}

Data were analysed using thematic categorical content analysis [15] including three phases: pre-analysis, examination of the material, and data processing and interpretation of results. The category of the data was defined based on the each of the research question. For example, if the research question was "What is the exclusive goal of psychological intervention that makes it unique when compared to any other profession or form of intervention?" the category was defined as "The exclusive goal of psychological intervention". Furthermore, authors independently read the three open question answers of the participants several times for pre-analysis. As next emergent themes and subcategories were identified based on the open question answers. This was done by analysing each answer and by coding the answers. The coding criteria were chosen semantics and lexicon, which means that those answers including word "support" were categorized in the subcategory Support. The title of the category was named basing on the lexicon, on literature review, and on the categories that were defined by Ricou and collaborators [1]. Finally, the frequency of themes was counted. To broaden the understanding of the frequency of each subcategory, authors calculated how many participants mentioned the subcategory in their answer and this was presented as percentage. Two independent researchers completed the content analysis.

\section{Results}

In the result of thematic categorical content analysis, subcategories were defined for the three categories (Table 1).

Table 1. Content analysis: categories and subcategories.

\begin{tabular}{|c|c|}
\hline Categories & Subcategories \\
\hline \multirow{21}{*}{$\begin{array}{l}\text { The exclusive goal of psychological } \\
\text { intervention }\end{array}$} & Support \\
\hline & Self-awareness \\
\hline & Promotion of emotional balance \\
\hline & Promotion of problem-solving skills \\
\hline & Psychological assessment \\
\hline & Promotion of change \\
\hline & In-depth approach to the topic \\
\hline & Resource awareness \\
\hline & Psycho-education \\
\hline & Strengthening the client \\
\hline & Evidence-based practice \\
\hline & Client-centred approach \\
\hline & Psychological help \\
\hline & Listening to client \\
\hline & Exclusive approach \\
\hline & Acceptance \\
\hline & Creation of safe environment \\
\hline & Promotion of mental health \\
\hline & Promotion of behaviour change \\
\hline & Identification of cognitive distortions \\
\hline & Understanding the individual \\
\hline
\end{tabular}


Table 1. Continued.

\begin{tabular}{|c|c|}
\hline & Therapeutic relationship \\
\hline & Decrease the suffering \\
\hline & Empathic approach \\
\hline & Counselling \\
\hline & Psychological assessment \\
\hline & Promotion of problem-solving skills \\
\hline & Psychological report \\
\hline & Support \\
\hline & Counselling \\
\hline & Research \\
\hline & Conversation \\
\hline & Promotion of emotional balance \\
\hline & Self-awareness \\
\hline & Goal-oriented approach \\
\hline & Client-centred approach \\
\hline The functions that are exclusively & Evidence-based practice \\
\hline performed by psychologists & Promotion of change \\
\hline & Resource awareness \\
\hline & Promotion of mental health \\
\hline & Intervention in crisis \\
\hline & Psycho-education \\
\hline & Human resources management \\
\hline & Relationship building \\
\hline & Defined by law \\
\hline & Protection of children's rights and interests \\
\hline & Unconditional acceptance \\
\hline & Promotion of development \\
\hline & Uniqueness \\
\hline & Support \\
\hline & Listening to client \\
\hline & Counselling \\
\hline & Psychological intervention \\
\hline & Unconditional acceptance \\
\hline & Human resources management \\
\hline & To promote problem-solving skills \\
\hline & Research \\
\hline The functions that are performed by & Collect information \\
\hline psychologists yet may also be performed & Self-awareness \\
\hline by other professionals & Conversation \\
\hline & Psycho-education \\
\hline & Psychological correction \\
\hline & None \\
\hline & Specific techniques of intervention \\
\hline & Promotion of emotional balance \\
\hline & Promotion of change \\
\hline & Coaching \\
\hline & All other, except psychological assessment \\
\hline
\end{tabular}


Further results are presented in line with the categories: 1) the exclusive goal of psychological intervention; 2) the functions that are exclusively performed by psychologists; 3 ) the functions that are performed by psychologists yet may also be performed by other professionals.

Regarding the first research question and the category of the exclusive goal of psychological intervention (PI), there is no consensus among psychologists. This can be observed from the great number of subcategories that emerged in this category. Overall, 25 subcategories are defined in this category (Table 2). Support (16\%), Self-awareness (16\%), Promotion of emotional balance (16\%), Promotion of problem-solving skills (14\%), Psychological assessment $(11 \%)$ and Promotion of change (11\%) have been named most often in the participant's answers which is in line with the frequency.

Table 2. Goals of PI: coding frequency according to subcategory.

\begin{tabular}{|c|c|c|c|}
\hline Categories & Subcategories & Frequency & $\begin{array}{c}\% \text { of } \\
\text { participants }\end{array}$ \\
\hline \multirow{25}{*}{$\begin{array}{l}\text { The exclusive } \\
\text { goal of } \\
\text { psychological } \\
\text { intervention }\end{array}$} & Support & 9 & 16 \\
\hline & Self-awareness & 9 & 16 \\
\hline & $\begin{array}{l}\text { Promotion of emotional } \\
\text { balance }\end{array}$ & 9 & 16 \\
\hline & $\begin{array}{l}\text { Promotion of problem-solving } \\
\text { skills }\end{array}$ & 8 & 14 \\
\hline & Psychological assessment & 6 & 11 \\
\hline & Promotion of change & 6 & 11 \\
\hline & In-depth approach of topic & 4 & 7 \\
\hline & Resource awareness & 4 & 7 \\
\hline & Psycho-education & 3 & 5 \\
\hline & Strengthening the client & 3 & 5 \\
\hline & Evidence-based practice & 3 & 5 \\
\hline & Client-centred approach & 3 & 5 \\
\hline & Psychological help & 3 & 5 \\
\hline & Listening to client & 2 & 4 \\
\hline & Exclusive approach & 2 & 4 \\
\hline & Acceptance & 2 & 4 \\
\hline & Creation of safe environment & 2 & 4 \\
\hline & Promotion of mental health & 2 & 4 \\
\hline & Promotion of behaviour change & 2 & 4 \\
\hline & $\begin{array}{l}\text { Identification of cognitive } \\
\text { distortions }\end{array}$ & 2 & 4 \\
\hline & Understanding the individual & 1 & 2 \\
\hline & Therapeutic relationship & 1 & 2 \\
\hline & Decrease the suffering & 1 & 2 \\
\hline & Empathic approach & 1 & 2 \\
\hline & Counselling & 1 & 2 \\
\hline
\end{tabular}

Regarding the exclusive activities of psychologists overall 24 categories were defined (Table 3). Of 56 psychologists who participated in this study, 63\% claim psychological assessment as an exclusive function of psychologists. The most frequently identified activities concern Promotion of problem-solving skills (18\%), Psychological report (16\%), Support (16\%), and Counselling (14\%). 
Table 3. Exclusive activities of psychologists: coding frequency according to subcategory.

\begin{tabular}{|c|c|c|c|}
\hline Categories & Subcategories & Frequency & $\begin{array}{c}\% \text { of } \\
\text { participants }\end{array}$ \\
\hline \multirow{24}{*}{$\begin{array}{l}\text { The functions } \\
\text { that are } \\
\text { exclusively } \\
\text { performed by } \\
\text { psychologists }\end{array}$} & Psychological assessment & 35 & 63 \\
\hline & $\begin{array}{l}\text { Promotion of problem-solving } \\
\text { skills }\end{array}$ & 10 & 18 \\
\hline & Psychological report & 9 & 16 \\
\hline & Support & 9 & 16 \\
\hline & Counselling & 8 & 14 \\
\hline & Research & 5 & 9 \\
\hline & Conversation & 4 & 7 \\
\hline & $\begin{array}{l}\text { Promotion of emotional } \\
\text { balance }\end{array}$ & 4 & 7 \\
\hline & Self-awareness & 4 & 7 \\
\hline & Goal-oriented approach & 4 & 7 \\
\hline & Client-centred approach & 3 & 5 \\
\hline & Evidence-based practice & 3 & 5 \\
\hline & Promotion of change & 3 & 5 \\
\hline & Resource awareness & 3 & 5 \\
\hline & Promotion of mental health & 2 & 4 \\
\hline & Intervention in crisis & 2 & 4 \\
\hline & Psycho-education & 2 & 4 \\
\hline & Human resources management & 2 & 4 \\
\hline & Relationship building & 1 & 2 \\
\hline & Defined by law & 1 & 2 \\
\hline & $\begin{array}{l}\text { Protection of children's rights } \\
\text { and interests }\end{array}$ & 1 & 2 \\
\hline & Unconditional acceptance & 1 & 2 \\
\hline & Promotion of development & 1 & 2 \\
\hline & Uniqueness & 1 & 2 \\
\hline
\end{tabular}

Similar to previous themes, many subcategories emerged from the participants' answers regarding activities that are performed by psychologists yet may also be performed by other professionals.

Regarding the activities performed by other professionals apart from psychologists, 19 categories are defined. Support was named most frequently $-36 \%$ of the participants named it as the activity that can be performed by other professionals besides psychologists. The other most commonly mentioned functions that are performed by psychologists yet may also be performed by other professionals are Listening to client (18\%), Counselling (16\%) and Unconditional acceptance (13\%).

\section{Discussion}

Looking at the results of the research, firstly, we notice that there is no consensus or tendency towards superiority among any of the issues raised in the research. Furthermore, results overlap in all the categories. For example, support was named in all three categories. Moreover, support has been described in different aspects such as emotional support, psychological support. It indicates the difference in the application of the terminology suggesting the diverse understanding of the psychological terms. 
Table 4. Activities performed by other professionals besides psychologists: coding frequency according to subcategory.

\begin{tabular}{|c|c|c|c|}
\hline Categories & Subcategories & Frequency & $\begin{array}{c}\% \text { of } \\
\text { participants }\end{array}$ \\
\hline \multirow{6}{*}{$\begin{array}{l}\text { The functions } \\
\text { that are } \\
\text { performed by } \\
\text { psychologists } \\
\text { yet may also be } \\
\text { performed by }\end{array}$} & Support & 20 & 36 \\
\hline & Listening to client & 10 & 18 \\
\hline & Counselling & 9 & 16 \\
\hline & Psychological intervention & 7 & 13 \\
\hline & Unconditional acceptance & 5 & 9 \\
\hline & Human resources management & 5 & 9 \\
\hline \multirow[t]{13}{*}{$\begin{array}{c}\text { other } \\
\text { professionals }\end{array}$} & $\begin{array}{l}\text { To promote problem-solving } \\
\text { skills }\end{array}$ & 5 & 9 \\
\hline & Research & 4 & 7 \\
\hline & Collect information & 4 & 7 \\
\hline & Self-awareness & 4 & 7 \\
\hline & Conversation & 3 & 5 \\
\hline & Psycho-education & 3 & 5 \\
\hline & Psychological correction & 3 & 5 \\
\hline & None & 2 & 4 \\
\hline & $\begin{array}{l}\text { Specific techniques of } \\
\text { intervention }\end{array}$ & 2 & 4 \\
\hline & $\begin{array}{l}\text { Promotion of emotional } \\
\text { balance }\end{array}$ & 2 & 4 \\
\hline & Promotion of change & 2 & 4 \\
\hline & Coaching & 1 & 2 \\
\hline & $\begin{array}{l}\text { All other, except psychological } \\
\text { assessment }\end{array}$ & 1 & 2 \\
\hline
\end{tabular}

As we can see, psychologists do not have a common understanding of the functions and goals of psychological intervention that are exclusive to psychologists and that distinguish them from other similar professionals and their professional activities. Ricou et al., looking at similar results in the Portuguese sample, indicated that this seems to show that even though psychologists may have little awareness of the goals of their profession, at least they are aware of its fundamental technical dimensions such as psychological assessment [1].

The Standard of the psychologist's profession clearly indicates the functions of a psychologist and the boundaries of the psychologist's professional activity. It states that the psychologist analyzes and applies the theoretical and empirically substantiated principles of psychology in the psychologist's professional activity. The psychologist sets goals for achieving professional activity, performs individual, group, or organization psychological research psychological assistance. In accordance with the set goal, the psychologist evaluates the efficiency of the professional activity, writes and provides the psychologist's opinion, and conducts scientific research. The psychologist cooperates with the representatives of their own and other professions, and in their professional activity, they observe the norms of professional ethics of a psychologist. The psychologist works in institutions and companies (including schools, hospitals, and clinics) or as a self-employed person or sole proprietor [16]. Limited agreement and comprehension of Latvian psychologists on their professional practice we can relate to a relatively large number (six) of areas of psychologists' professional activity. As mentioned above, they are educational and school psychology; psychology of 
work and organizations; clinical and health psychology; legal psychology; consultative psychology; military psychology. Each of them is characterized by specific types/directions of activity, professional activity environment, client/patient groups, as well as a circle of cooperation professionals [17], as well as with the long period of development of the psychologist profession, which is characterized by different educational approaches, requirements, and traditions up to the complete arrangement of the profession legislation.

The limitations of the research can also be highlighted here - a relatively small sample of psychologists and an uneven distribution by fields of professional activity. However, the results of the research reveal several contradictions, which may indicate the uncertainty and weakness of the boundaries of the professional activities of psychologists.

There is a need for further research with a larger sample, focusing on the six areas of psychologist's professional activity. This would broaden the perspective and indicate more precisely the differences of psychologists understanding of their exclusive goal of psychological intervention and performed functions in the Latvian sample.

\section{Conclusion}

Overall, it can be stated that there is limited agreement and comprehension among Latvian psychologists regarding the three categories 1) the exclusive goal of psychological intervention; 2) the functions that are exclusively performed by psychologists; 3) the functions that are performed by psychologists yet may also be performed by other professionals. The large number of subcategories indicates the fragmented opinion of psychologists. This is in line with similar study completed in Portugal [1] and, generally, this raises a question about the professional identity of psychologists. Results indicate the need to develop common understanding of the goals of psychological intervention and performed functions. Thus, this research has given a perspective that needs to be further discussed with the psychologists to determine solutions on how to strengthen psychologist's professional identity.

\section{References}

[1] M. Ricou, S.A. Cordeiro, A.R. Franco, C. Costa - Labo,The Identity of Psychology. The Psychologist: Practice \& Research Journal (2018)

[2] V.L. Vignoles, S.J. Schwartz, K. Luyckx, Toward an integrative view of identity. In: S.J. Schwartz, K. Luyckx V.L. Vignoles, eds. Handbook of Identity Theory and Research (Springer, New York, 2011)

[3] V.B. Skorikov, F.W. Vondarcek, Occupational identity. In: S.J. Schwartz, K. Luyckx, V.L. Vignoles, eds. Handbook of Identity Theory and Research (Springer, New York, 2011)

[4] H. Tajfel, J. Turner, An integrative theory of integroup conflict, chapter 3, In W.G. Austin, S. Worchel, eds. The Social psychology of intergroup relations (Brooks/ColePub.Co., Monterey, 1979)

[5] K. Adams, K.S. Hean, P. Sturgis, J. Clark, Learning in Health and Social Care, 5(2), 55-68, (2006)

[6] E.A. Mellin, B. Hunt, L.M. Nichols, Counselor professional identity: findings and implications for counseling and interprofessional collaboration. Journal of Counseling $\mathcal{E}$ Development, Spring 89 (2011)

[7] I. Cardoso, P. Batista, A. Graça, Professional identity in analysis: a systematic review of the literature. Open Sports Sciences Journal 7(Sept), 83-97 (2014) 
[8] S.B. Nicholls, R.E. Rice, A Dual - Identity Model of Responses to Deviance in Online Groups: Integrating Social Identity Theory and Expectancy Violations Theory. Communication Theory 27, 243-268 (2017)

[9] J.L. Davis, T.P. Love, P. Fares, Collective Social Identity: Synthesizing Identity Theory and Social Identity Theory Using Digital Data Social. Psychology Quarterly 82(3), 254273 (2019)

[10] L. Cowin, M. Johnson, I. Wilson, K. Borgese, The psychometric properties of five Professional Identity measures in a sample of nursing students. Nurse Education Today 33(6), 608-613 (2013)

[11] S. Spurgeon, Counselor identity - a national imperative. Journal of Professional Counseling, Practice, Theory, $\mathcal{F}$ Research 39(1), 3 (2012)

[12] K. Mārtinsone, A. Lasmane, Ā. Karpova, Psihologijas vēsture (Zvaigzne ABC, Rīga, 2016)

[13] K. Mārtinsone, I.J. Mihailovs, Psihologa izglītības sistēma Latvijā. In K. Mārtinsone un B. Girgensone eds. Psihologu profesionālā darbība Latvijā: saturs, organizācija, regulējums. Psihologu likuma komentāri, 25-42 (Tiesu namu à̀entūra, Rīga, 2018)

[14] Law on Psychologists. Retrieved from: https://likumi.lv/ta/id/290115-psihologulikums07.07.2021

[15] L. Bardin, Análise de Conteúdo, 70 (Edicões, Lisboa, 2009)

[16] Standard of the profession of psychologist, Retreived from: https://registri. visc.gov.lv/profizglitiba/dokumenti/standarti/2017/PS-108.pdf 07.07.2021

[17] G. Dāvidsone, J. Koḷesṇikova, Psihologa profesionālās darbības jomas. In K. Mārtinsone un B. Girgensone eds. Psihologu profesionālā darbība Latvijā: saturs, organizācija, regulējums. Psihologu likuma komentāri, 117-130 (Tiesu namu aǵentūra, Rīga, 2018) 